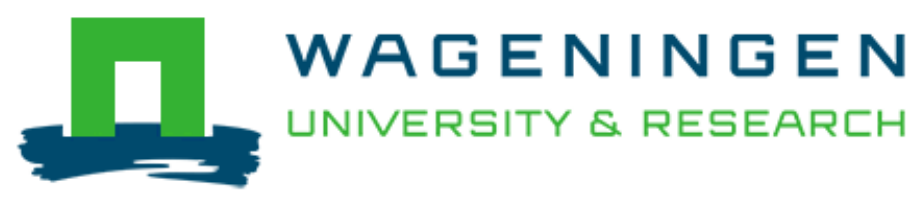

\author{
Testing the relationship between personality characteristics, contextual \\ factors and entrepreneurial intentions in a developing country \\ Karimi, S., Biemans, H. J. A., Naderi Mahdei, K., Lans, T., Chizari, M., \& \\ Mulder, M.
}

This article is made publically available in the institutional repository of Wageningen University and Research, under article 25fa of the Dutch Copyright Act, also known as the Amendment Taverne.

Article $25 \mathrm{fa}$ states that the author of a short scientific work funded either wholly or partially by Dutch public funds is entitled to make that work publicly available for no consideration following a reasonable period of time after the work was first published, provided that clear reference is made to the source of the first publication of the work.

For questions regarding the public availability of this article, please contact openscience.library@wur.nl.

Please cite this publication as follows:

Karimi, S., Biemans, H. J. A., Naderi Mahdei, K., Lans, T., Chizari, M., \& Mulder, M. (2017). Testing the relationship between personality characteristics, contextual factors and entrepreneurial intentions in a developing country. International Journal of Psychology, 52(3), 227-240. https://doi.org/10.1002/ijop.12209 


\title{
Testing the relationship between personality characteristics, contextual factors and entrepreneurial intentions in a developing country
}

\author{
Saeid Karimi ${ }^{1}$, Harm J.A. Biemans ${ }^{2}$, Karim Naderi Mahdei ${ }^{1}$, Thomas Lans ${ }^{2}$, \\ Mohammad Chizari ${ }^{3}$, and Martin Mulder ${ }^{2}$ \\ ${ }^{1}$ Department of Agricultural Education and Extension, Faculty of Agriculture, Bu-Ali Sina \\ University, Hamedan, Iran \\ ${ }^{2}$ Department of Social Sciences, Education and Competence Studies Group, Wageningen \\ University, Wageningen, the Netherlands \\ ${ }^{3}$ Department of Agricultural Education and Extension, Agricultural College, Tarbiat Modares \\ University, Tehran, Iran
}

\begin{abstract}
$D$ rawing upon the theory of planned behaviour (TPB), we developed and tested a conceptual model which integrates both internal personality factors and external contextual factors to determine their associations with motivational factors and entrepreneurial intentions (EIs). We then investigated if the model of EI applies in a developing country, namely Iran. We also set out to identify the most relevant factors for EI within this developing country context. Do distal predictors of EI including personality factors (i.e. need for achievement, risk taking and locus of control) and contextual factors (i.e. perceived barriers and support) significantly relate to EI via proximal predictors including motivational factors (i.e. attitudes towards entrepreneurship and perceived behavioural control [PBC])? Data were collected on 331 students from 7 public universities. The findings support the TPB for EI in Iran. All three motivational factors related to EI, but PBC showed the strongest association, which is different than in developed country contexts. Possible explanations for these differences are discussed. All three personality characteristics indirectly related to EI via the proximal attitudes towards entrepreneurship and PBC. Perceived contextual support and barriers indirectly related to EI via proximal PBC while perceived barriers also directly related to EI.
\end{abstract}

Keywords: Entrepreneurial intentions; Theory of planned behaviour; Personality characteristics; Contextual factors; Developing country; Iran.

Given the positive effects of entrepreneurship on a country's economy in the form of the creation of employment opportunities and economic growth, the promotion of entrepreneurship is a national priority for many governments around the world and particularly those in developing countries. Yet, little is known about the promotion of entrepreneurship in developing countries because the focus of most research to date has been on the promotion of entrepreneurship in developed countries (Bruton, Ahlstrom, \& Obloj, 2008). What we know about entrepreneurship in developed economies, moreover, may not readily apply to entrepreneurship in developing economies (Bruton et al., 2008). Studies of entrepreneurship have shown entrepreneurial activities and their antecedents to depend on the specific social, cultural, economic, legal and political contexts, which differ significantly across countries and thus limit the generalisation of research results from developed to developing country contexts (Bruton et al., 2008). By developing countries, we mean those which can be characterised as middle-income economies using the World Bank (2011) classification.

Developing countries like Iran typically have very different socio-cultural and politico-institutional environments than developed countries and these varying environments can relate differently to: entrepreneurial attitudes and motivations; the resources which can be mobilised for business start-ups; and both the constraints

Correspondence should be addressed to Saeid Karimi, Department of Agricultural Extension and Education, Faculty of Agriculture, Bu-Ali Sina University, 65178 33131, Hamedan, Iran. (E-mail: skarimi@ basu.ac.ir). 
and opportunities for starting and running a business (Welter \& Smallbone, 2011).

Entrepreneurship begins when an individual decides to undertake a new venture. In order to foster greater entrepreneurship, it is therefore necessary to understand just how people reach the decision undertake a new venture. There is a growing body of literature showing entrepreneurial intentions (EIs) to play an important role in the decision to start a new business. Less is known about the factors affecting EI, however, particularly in developing countries (Nabi \& Linan, 2013). In a study by Schlaegel and Koenig (2014) meta-analysis of the determinants of EI, more than two-thirds of the studies had been conducted in developed as opposed to developing economies. The existing comparisons showed determinants of EI to clearly vary across countries and thus differ for developed versus developing countries (e.g. Iakovleva, Kolvereid, \& Stephan, 2011; Schlaegel \& Koenig, 2014). Fishbein and Ajzen (2010) found that the institutional environment influences the formation of intentions through the shaping of perceptions and the beliefs, which individuals hold about behaving in a given manner.

Research on EI shows many factors to relate to the individual's intention to start a business, including the individual's personality and the environmental context (Lüthje \& Franke, 2003; Nabi \& Linan, 2013). In addition to the existing focus on developed countries and the neglect of developing countries in the literature, little research has taken both internal psychological factors (e.g. risk-taking, need for achievement) and external environmental factors (e.g. socioeconomic conditions, financial support) into consideration when examining new venture creation (Lüthje \& Franke, 2003; Nabi \& Linan, 2013; Taormina $\&$ Lao, 2007). Very few empirical studies have examined the relative contributions of these factors to new venture creation in developing economies. The main purpose of the present research was therefore to examine whether Western models of EI also apply in a developing country context and, if so, whether the model explains comparable amounts of variance as in developed countries. Do the same factors which have been shown to relate to the EI of students in developed countries also relate to the EI of Iranian students? And which factors appear to be the most relevant for EI in an Iranian context?

Both psychological and environmental factors are examined within a comprehensive, multidimensional model of entrepreneurship. The relative importance of these variables for EI is examined particularly with respect to the theory of planned behaviour (TPB). In the past, research has concentrated on mostly the direct effects of personality factors and environmental factors on entrepreneurship and EI. The present approach with its attention to both the direct and indirect effects of numerous psychological and environmental variables is thus novel.

\section{Iranian context}

Iran is a developing country with a rich and ancient cultural heritage and a position of both strategic and economic importance within the Persian Gulf and beyond. During the past decade in Iran, the government has developed an increased interest in the stimulation of entrepreneurship to provide a solution for the problem of high youth unemployment and to stimulate the economy. The government is spending more than ever to develop institutions to support business development, encourage entrepreneurship and stimulate innovation in higher education, policy-making and business (Karimi, Chizari, Biemans, \& Mulder, 2010). Despite these efforts, entrepreneurial activity has not developed greatly in recent years, and this sector in Iran is still seriously underdeveloped when compared with developed countries. According to the Global Entrepreneurship Monitor (GEM) report in 2013 (Amoros \& Bosma, 2014), Iran ranks about "average" among the 67 current GEM member countries in terms of most entrepreneurship indices (including total entrepreneurial activity, intentions, perceived entrepreneurial opportunities and capabilities, the social status of entrepreneurs and media attention for entrepreneurship). However, about $38 \%$ of all start-ups are driven by necessity in Iran while this is about $18 \%$ of all start-ups in developed economies.

According to a very recent World Bank (2014) report, Iran ranks 130th among 189 countries with respect to the ease of doing business; 62nd in starting a business; 89th for the ease of getting credit and 161th for the ease of property registration. In addition, economic and political conditions are less stable in developing countries like Iran than in developed countries (Karimi et al., 2010). An unstable economic and political context is usually unfavourable to becoming an entrepreneur due to a range of barriers (including uncertainty, turbulence, high rate of inflation, low credit repayment rate and an otherwise volatile environment). However, an unstable economy in a country like Iran also offers opportunities for entrepreneurial activities - possibly to a greater extent than stable, developed economies (Iakovleva et al., 2011).

\section{THEORETICAL FRAMEWORK}

\section{Entrepreneurship and the TPB}

Social psychological research has shown intention to be the single best predictor of planned individual behaviour, especially when the behaviour is rare, difficult to observe or involves unpredictable time lags (Krueger, Reilly, \& Carsrud, 2000). Entrepreneurship is an example of such planned, intentional behaviour. EI can be understood as the first step in the long-term process of starting a new business. EI has indeed been shown to be a primary 
predictor of future entrepreneurial behaviour (Kautonen, van Gelderen, \& Fink, 2015; Kolvereid \& Isakson, 2006).

Early research which has focused on specific personality traits and demographic characteristics as the sole predictors of EIs and the behaviour has been criticised for its low predictive capacity (Krueger et al., 2000). In response to these criticisms, researchers have turned to more cognitive models of EI and behaviour. The most commonly used model is that drawing on the TPB (Schlaegel \& Koenig, 2014), as introduced by Ajzen (1991). The TPB model stresses three motivational antecedents which have been shown to affect the intention to engage in behaviour or, in the present case, new venture creation: (a) attitudes towards entrepreneurship (ATE) or the positive valuation of the initiation of a new venture; (b) subjective norms (SNs) or perceived social pressure to either become or not become an entrepreneur and (c) perceived behavioural control (PBC) or the perceived ease/difficulty of becoming an entrepreneur. $\mathrm{PBC}$ is conceptually similar to self-efficacy as originally proposed by Bandura (1977). For both constructs, the sense of capacity to perform a planned activity stands central. However, recent work has suggested that PBC is wider than self-efficacy because PBC subsumes both self-efficacy and the perceived controllability of behaviour (Ajzen, 2002).

Researchers have empirically applied the TPB to students' EIs and confirmed that ATE, SN and PBC all play significant roles (Iakovleva et al., 2011; Karimi, Biemans, Lans, Chizari, \& Mulder, 2014; Krueger et al., 2000; Linan \& Chen, 2009). The outcomes of the aforementioned studies nevertheless show marked variation across situations and countries in the relative importance of the antecedents and the magnitude of their influences. We can thus assume that the three motivational antecedents of EI are important but that socio-cultural and economic contexts modulate the relative importance and magnitude of their effects on EI.

Consideration of these findings led us to hypothesise the following for the relationships between Ajzen's motivational antecedents and EI.

\section{H1: (a) ATE, (b) SNs and (c) PBC will positively relate to Iranian students' EIs.}

According to the TPB, exogenous influences or more distal factors such as personality characteristics and contextual conditions can affect the behavioural intentions of individuals indirectly via their influences on more proximal, motivational factors such as ATE and PBC (Fishbein \& Ajzen, 2010). Of the three proposed motivational antecedents of EI within our model (i.e. SN, ATE and $\mathrm{PBC}$ ), the latter two have been shown to relate most strongly to not only EI (e.g. Karimi et al., 2014; Linan \& Chen, 2009) but also both personality factors (Fini, Grimaldi, Marzocchi, \& Sobrero, 2012; Lüthje \& Franke, 2003; Nabi \& Linan, 2013; Obschonka, Silbereisen,
\& Schmitt-Rodermund, 2010; Zhao, Seibert, \& Hills, 2005) and contextual factors (Fini et al., 2012; Goethner, Obschonka, Silbereisen, \& Cantner, 2012). According to the entrepreneurship literature (Fini et al., 2012; Goethner et al., 2012; Nabi \& Linan, 2013), SNs are less relevant than ATE and PBC for EI because entrepreneurs can be generally characterised as more inner-as opposed to outward-directed and thus less oriented towards social norms than non-entrepreneurs (Goethner et al., 2012). In the following, we therefore analyse the associations of personality and contextual factors with ATE and PBC but also EI in greater detail.

\section{TPB and personality factors}

Although approaches calling upon personality traits to understand EI have been criticised because such traits have been found to only bear a weak relationship to EI, personality may still play an important, more distal role in the entrepreneurial process and creation of new ventures (Shaver \& Scott, 1991). A number of scholars have indeed argued that the trait approach cannot simply be dismissed and that it still provides a number of promising avenues for exploration (Baum, Locke, \& Smith, 2001; Rauch \& Frese, 2007b). According to Zhao and Seibert (2006), personality must be treated as an important component of any multidimensional model of entrepreneurship and new venture creation. This has led to the idea that personality characteristics may affect entrepreneurial outcomes but not in isolation and probably via more proximal factors such as human/social capital and motivational factors (Baum et al., 2001). In entrepreneurship research, however, these mediating relationships have only received scant attention (Rauch \& Frese, 2007a).

Three personality characteristics that are often associated with entrepreneurship are need for achievement (nAch), a propensity towards risk taking and locus of control. We selected these personality characteristics because they have frequently been identified as part of the entrepreneurial personality and have proven their importance in affecting the level of aspiration for entrepreneurship (Lüthje \& Franke, 2003; Rauch \& Frese, 2007b; Robinson et al., 1991; Shaver \& Scott, 1991).

\section{Personality characteristics and ATE}

McClelland (1961) characterised individuals with high nAch as those preferring to be personally responsible for solving problems, setting goals and reaching these goals via their own efforts. Such individuals also tend to be dutiful, responsible and hardworking with a strong desire to be successful. Individuals with a high nAch are more likely to demonstrate entrepreneurial behaviour than other individuals, spot opportunities and act on opportunities. On the basis of these demonstrated 
characteristics, McClelland suggested that entrepreneurs should have high nAch. A high nAch predisposes an individual to seek out entrepreneurial positions rather than other career positions and thereby attain their desired achievement satisfaction. Those high on nAch can thus be expected to have more positive attitudes towards an entrepreneurial career choice.

Locus of control refers to the degree to which an individual generally perceives events to be under their own control (internal locus) or under the control of powerful others (external locus) (Rotter, 1966). Individuals who have little confidence in their ability to control their environment can thus be expected to be uninclined towards entrepreneurship and the risks of starting a business (Mueller \& Thomas, 2001). Conversely, individuals who have marked confidence in their ability to control their environment can be expected to be attracted to the control and individual responsibility which running a business entail and thus more favourable ATE than other individuals.

The entrepreneurial process generally requires individuals to deal with minimally structured and highly uncertain possibilities while also taking responsibility for the outcomes of often risky decisions: The creation of new ventures is an inherently risk-laden process. Accordingly, more risk tolerant individuals are found to "self-select" for an entrepreneurial career (Stewart \& Roth, 2001). Stated differently, entrepreneurship is a career path characterised by considerable risk and uncertainty, which renders entrepreneurship attractive to individuals with a high propensity for risk-taking. In light of this, it can be expected that people with a propensity to take risks will hold more positive ATE than individuals with no such propensity. Empirical studies have indeed shown risk-taking propensity and internal locus of control to be related to the ATE among students (e.g. Fini et al., 2012; Lüthje \& Franke, 2003). Soomro and Shah (2015) also recently found need for achievement to positively and significantly relate to ATE.

Drawing on these findings, we have assumed that (a) a higher need for achievement, (b) a propensity to take risks and (c) a more internal than external locus of control will all be associated with more favourable ATE.

\section{Personality characteristics and PBC}

Individuals with a high $n A c h$ tend to be hardworking, persistent and determined. Such individuals tend to feel more capable, perform better and have a higher ability to prevail under difficult circumstances than individuals with a low nAch. They also typically have a high sense of self-efficacy, a marked desire to tackle challenging goals and a strong need to be successful (Lumpkin \& Erdogan, 1999). Individuals with a high nAch can thus be expected to strongly believe in their ability to establish a new business with ease, control the creation process and thus a higher EI than other individuals. In other words, we expect $\mathrm{PBC}$ to be higher for individuals showing a higher nAch.

People with a more internal than external locus of control may also have high expectations for their ability to control outcomes. In a similar vein, they are likely to believe that they can establish a new business with some ease. Those who view outcomes as self-determined and also see themselves having the skills needed for such self-determination have been shown to have high levels of self-efficacy (Bandura, 1977). In addition, perceived controllability has been found to be associated with greater levels of confidence an individual has in his or her ability to take action (Phillips \& Gully, 1997). It is therefore reasonable to expect that individuals with a more internal as opposed to external locus of control will have a higher level of PBC as well (feelings of self-efficacy and controllability).

The relationship between risk-taking and $\mathrm{PBC}$ has also been investigated in the entrepreneurship literature but on a very limited basis. As Zhao et al. (2005) argue, propensity for risk-taking can be expected to be associated with the individual's perceptions of his/her physiological state (i.e. arousal) when taking a risk and thus, for example, when starting a new venture. Individuals with a higher propensity for risk-taking will tend to feel more comfortable with risk-taking and therefore experience less anxiety when doing this but also judge their likelihood of succeeding more highly than others (i.e. have greater self-efficacy than others; Zhao et al., 2005). These same individuals can similarly be expected to have a greater sense of control over their own behaviour and the environment (Zhao et al., 2005) and therefore perceive themselves as having considerable control when it comes to the start of a new business. We can therefore postulate that individuals with a higher propensity for risk-taking will also have a higher level of PBC.

Based on all of these findings, the following hypotheses were tested in our research.

H2: The need for achievement will positively relate to (a) ATE and (b) $P B C$.

H3: Propensity towards risk-taking will positively relate to (a) ATE and (b) PBC.

H4: Locus of control will positively relate to (a) ATE and (b) $P B C$.

\section{TPB and contextual factors}

According to institutional economic theory (North, 2005), environmental or contextual factors can be 
assumed to play an important role in individual attitudes and economic behaviour, including entrepreneurship. Contextual factors can define, create, facilitate or limit entrepreneurial aspirations, intentions, opportunities, activities and entry rates (e.g. Lüthje \& Franke, 2003). However, little attention has been paid to the role of contextual factors in new business creation-particularly in developing economies (Bruton et al., 2008).

The TPB provides a suitable framework for exploring the effects of the environment on the individual entrepreneurial process (Ajzen, 1991; Shapero, 1982). The TPB states that underlying ATE and PBC are salient beliefs which "are not innate but instead are acquired in daily encounters with the real world" (Fishbein \& Ajzen, 2010, p. 224). It is further assumed within the TPB that contextual factors can exert direct effects on behavioural intentions in addition to indirect effects via the TPB factors (Fishbein \& Ajzen, 2010). The valuation of environmental conditions by potential entrepreneurs can profoundly and either positively or negatively shapes their intention to start a new business - over and beyond the effects of such TPB factors as ATE and PBC (Nabi \& Linan, 2013).

Some scholars (e.g. Taormina \& Lao, 2007) argue that subjective perceptions of the environment should be measured because they can be expected to be more influential than the actual environmental factors themselves. A large number of contextual factors have been proposed in the literature to influence the intention to engage in entrepreneurship activities and many different measures have been used to assess these factors (e.g. Busenitz, Gomez, \& Spencer, 2000; Fini et al., 2012). However, when Lüthje and Franke (2003) conducted an exhaustive analysis of such contextual factors in qualitative interviews and quantitative surveys of business students, they found that the students' perceptions of contextual factors could be differentiated into perceived barriers to entrepreneurship (e.g. restricted credit conditions, limited access to finance) and perceived support for entrepreneurship (e.g. consultancy services, university support). Based on the synthesis of the relevant literature (Fini et al., 2012; Fishbein \& Ajzen, 2010; Goethner et al., 2012; Lüthje \& Franke, 2003; Nabi \& Linan, 2013; Taormina \& Lao, 2007), we therefore examined both the direct and indirect associations of perceived barriers and perceived support with EI.

\section{Indirect effects of perceived contextual support}

Positive perceptions of contextual support can be expected to positively relate to the individual evaluation of entrepreneurship or ATE (Shapero, 1982). When the individual perceives environmental conditions as favourable to entrepreneurship (e.g. university, social or financial support), their attitudes towards starting a business may be more favourable as well.

Perceived contextual support can be expected to relate to $\mathrm{PBC}$ as well. The more resources the individual thinks they possess, the fewer obstacles and impediments they will anticipate and thus the greater their PBC as a result (Ajzen, 1991). In other words, the resources available to the individual can correlate-at least in part - with the likelihood of behavioural achievement (Ajzen, 1991). Access to resources such as funds and information can give the individual the confidence to step into an otherwise uncertain situation or occupation such as entrepreneurship.

\section{Indirect effects of perceived contextual barriers}

Perceptions of contextual barriers can be expected to relate to ATE. When the individual perceives environmental conditions as unfavourable to entrepreneurship (e.g. restricted credit conditions, limited access to funds), their attitudes towards starting a business may become unfavourable. Perceived barriers to entrepreneurship may similarly limit an individual's ability to start a new business by lowering their confidence in their ability to do this. When students perceive the environment as unconducive to starting a business, they will generally be more pessimistic about both the possibilities of starting a business and their ability to do this. Perceived contextual barriers can thus be expected to directly but negatively relate to both ATE and PBC and indirectly but negatively relate to EI.

\section{Direct effects of contextual factors}

Contextual factors may also affect EI directly and thus operate independent of ATE, SN and PBC. According to Lüthje and Franke (2003), contextual factors can be seen to facilitate or hinder entrepreneurial activities when the individual makes, for example, an economic assessment of the expected costs and benefits of pursing an entrepreneurial career path. An individual may be willing to start a new business despite initially negative ATE when the business environment is perceived as favourable to entrepreneurship and thus acts as a trigger for an EI. When individuals see that they can get consultants and support for the establishment of a business, they will presumably be more inclined to initiate a new venture than when this support is not readily available. Conversely, when an individual holds initially positive ATE but perceives the business environment as unfavourable and unsupportive of entrepreneurship, they will generally be more likely to decide against the start of a new business than when contextual conditions are perceived as more favourable. Lack of banking support and restrictive national laws may 
similarly discourage EI (Lüthje \& Franke, 2003). The environmental context can thus be expected to discourage or encourage the individual's intentions to start a business (Lüthje \& Franke, 2003; Nabi \& Linan, 2013).

In line with the above-mentioned details, we tested the following hypotheses.

H5: Perceived contextual support will positively relate to (a) ATE, (b) PBC and (c) EIs.

H6: Perceived contextual barriers will negatively relate to (a) ATE, (b) PBC and (c) EIs.

\section{METHODS}

\section{Sample and data collection}

In our study, 400 Bachelor of Science (BSc) and Master of Science (MSc) students who had participated in entrepreneurship courses at seven Iranian public universities during the academic year 2010-2011 were approached. A convenience sample was thus used as is frequently done in entrepreneurship research (Karimi et al., 2014; Krueger et al., 2000; Linan \& Chen, 2009). A total of 346 questionnaires were returned, which is a response rate of $87 \%$. The questionnaire responses were screened for missing data and outliers (Hair, Black, Babin, \& Anderson, 2010). Following this validation process, 331 questionnaires proved useful. All the items reflecting the independent and dependent variables were responded to along a 7-point Likert scale ranging from 1 indicating "strongly disagree" to 7 indicating "strongly agree." The demographic characteristics of the sample are presented in Table 1.

\section{RESULTS}

\section{Exploratory factor analysis}

The structure of the 42 items used to measure the nine key constructs in the hypothesised model was examined in an exploratory factor analysis. Eight items which loaded weakly $(<0.5)$ or cross loaded $(>0.4)$ were omitted from further analysis. All the factor loadings for the 34 items in the new analysis were acceptable $(>0.5)$, which provided support for the measurement instrument (Figure 1).

\section{Structural equation modelling}

According to Hair et al. (2010), a two-step approach can be adopted for structural equation modelling (SEM): (a) assessment of the proposed measurement model and (b) assessment of the structural model. In the first step, a confirmatory factor analysis (CFA) was conducted to check the reliability and construct validity of the proposed measurement model. The proposed model with a total of nine constructs fit the data reasonably well $\left(\chi^{2}=767.34 ; \quad \chi^{2} / d f=1.595 ; \quad\right.$ GFI $=.884 ; \quad$ TLI $=.922 ;$ $\mathrm{CFI}=.933$; IFI $=.935$; RMSEA $=.042$ ). The CFA results also demonstrated the discriminant merit of the nine constructs with critical ratios for the factor loadings (critical ratio $=t)$ all exceeding $5.93(p<0.01)$ and factor loadings all greater than 0.50 . In addition, all the nine constructs showed construct reliabilities which were greater than the recommended 0.70 (Nunnally \& Bernstein, 1994), and the average variance extracted (AVE) estimate for all the constructs was above or close to the recommended threshold of 0.50 (Hair et al., 2010; see Table 2).

According to Hair et al. (2010), if the square root of the AVE estimate for each construct is greater than the correlation between that and all the other constructs in the model, then discriminant validity has been demonstrated. As shown in Table 3, this was found to be the case for all the constructs. In addition, the correlations in Table 3 are all moderate to low, which shows no evidence of multicollinearity.

Once a satisfactory measurement model was obtained, the second step in our analyses was undertaken, namely assessment of the structural model. The overall goodness of fit statistics showed the structural model to fit the data well (see Figure 2). To determine whether this model provided the best fit for the data, we also tested three

TABLE 1

Demographic characteristics of respondents

\begin{tabular}{lll}
\hline Variable & Value \\
\hline $\begin{array}{l}\text { Age } \\
\text { Gender }\end{array}$ & $\begin{array}{l}\text { Mean 22.46 years } \\
\text { Male 127 (38.4\%) }\end{array}$ & $\begin{array}{l}\text { Female 204 }(61.6 \%) \text {. There were more females in the sample because more females than males } \\
\text { were enrolled in the degree programmes offering the entrepreneurship courses and about } 60 \% \\
\text { of the general Iranian university population is female. } \\
\text { MSc } 76(23 \%)\end{array}$ \\
$\begin{array}{l}\text { Level of education } \\
\text { Academic major }\end{array}$ & $\begin{array}{c}\text { BSc } 255(77 \%) \\
\text { Business } 76(23 \%)\end{array}$ & $\begin{array}{l}\text { Humanities. There were more students of agricultural science in the sample because the } \\
\text { majority of the students participating in the entrepreneurship courses at the time of the conduct } \\
\text { of this research came from that field. }\end{array}$ \\
\hline
\end{tabular}




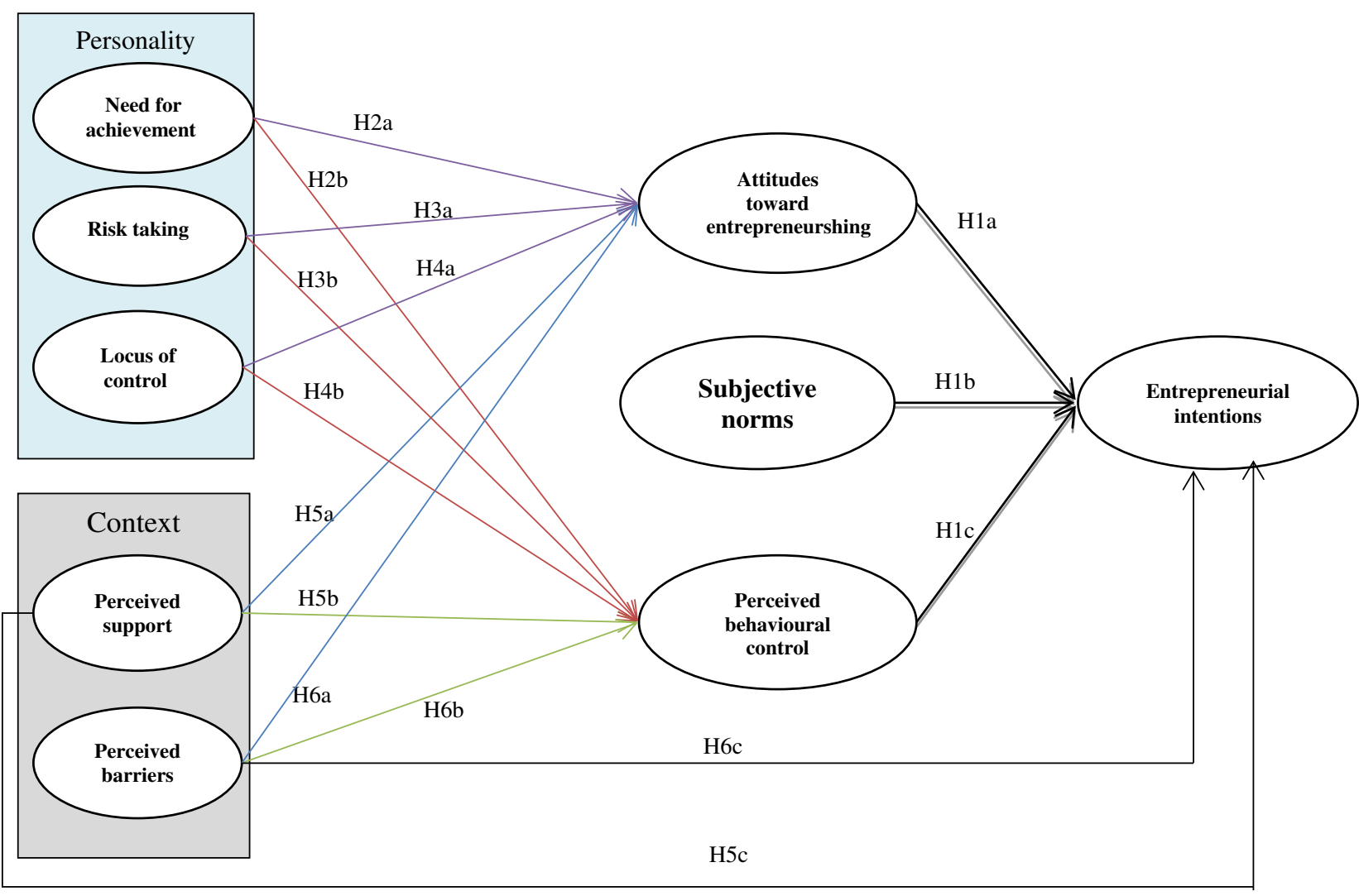

Figure 1. Proposed model for entrepreneurial intention.

other models. To create the other models, direct paths were added from the variables of need for achievement, risk-taking and locus of control to EI. The addition of these paths was suggested by the significant correlations of these variables with EI. The SEM results showed no significant improvement in the fit of the structural model; the contributions of the added paths were non-significant $(p>.05)$. The original proposed structural model thus provided the best fit for the data and could therefore be used to evaluate our hypotheses.

As can be seen from Table 4 and Figure 2, we found evidence to support our first three hypotheses and thus the expected associations of ATE (H1a: $\beta=.28$ ), SNs (H1b: $\beta=.13$ ) and PBC (H1c: $\beta=.64)$ with EI. Need for achievement and locus of control also significantly related to both ATE (H2a: $\beta=.23$; H4a: $\beta=.23$ ) and PBC (H2b: $\beta=.32 ; \mathrm{H} 4 \mathrm{~b}: \beta=.16)$ while risk-taking related to only PBC significantly $(\mathrm{H} 3 \mathrm{~b}): \beta=.21)$ and ATE marginally (H3a): $\beta=.12$ ). The rejection of the alternative models which included a direct path from each of the personality characteristics to EI shows the correlations of these factors with EI to be fully mediated by the motivational factors of ATE and PBC. In other words, personality characteristics do not directly correlate with EI but, rather, the motivational precursors to such intentions.
With regard to the effects of contextual factors, the path analyses showed perceived support and perceived barriers to directly relate to only PBC (H5b: $\beta=.16$; H6b: $\beta=-.12$ ). Perceived barriers also related directly to EI (H6c: $\beta=-.13$ ).

Together, the nine variables included in our model accounted for $61 \%$ of the variance in EI. The combined effects of personality characteristics and perceived contextual factors explained $16 \%$ of the variance in ATE and $24 \%$ of the variance in PBC, respectively. Data were thus found to support our hypotheses with the exceptions of $\mathrm{H} 5 \mathrm{a}, \mathrm{H} 5 \mathrm{c}$ and H6a.

\section{Effects of decomposition of the proposed model}

Effect decomposition analyses were conducted to provide additional information on the total effects of each of the personality factors and perceived contextual factors on EI. As can be seen from Table 5, need for achievement contributed the most of the distal factors to the prediction of EI (0.28). Together, the personality characteristics had a total effect of 0.61 on EI $(0.28+0.17+0.16)$. The contextual factors of perceived support and perceived barriers 
TABLE 2

Results of confirmatory factor analysis for proposed measurement model

\begin{tabular}{|c|c|c|c|c|c|c|}
\hline Latent variable & Items & Loading & $t$-value & $C R$ & $A V E$ & Cronbach's $\alpha$ \\
\hline \multirow[t]{5}{*}{ Entrepreneurial intentions } & Y1: I'm ready to make anything to be an entrepreneur. & .65 & & \multirow[t]{5}{*}{.84} & \multirow[t]{5}{*}{.52} & \multirow[t]{5}{*}{.84} \\
\hline & Y2: My professional goal is to become an entrepreneur. & .75 & $10.74^{*}$ & & & \\
\hline & $\begin{array}{l}\text { Y3: I will make every effort to start and run my own } \\
\text { business. }\end{array}$ & .77 & $11.50 *$ & & & \\
\hline & Y4: I'm determined to create a firm in the future. & .74 & $11.02 *$ & & & \\
\hline & Y5: I have very seriously thought in starting a business. & 68 & $8.73 *$ & & & \\
\hline \multirow[t]{4}{*}{ Attitudes towards entrepreneurship } & $\mathrm{X} 1$ : A career as an entrepreneur is totally unattractive to me. & .54 & & \multirow[t]{4}{*}{.82} & \multirow[t]{4}{*}{.55} & \multirow[t]{4}{*}{.80} \\
\hline & $\begin{array}{l}\text { X2: If I had the opportunity and resources, I would love to } \\
\text { start a business. }\end{array}$ & .63 & $9.54 *$ & & & \\
\hline & X3: Being an entrepreneur would give me great satisfaction. & .85 & $9.90^{*}$ & & & \\
\hline & $\begin{array}{l}\text { X4: Being an entrepreneur implies more advantages than } \\
\text { disadvantages to me. }\end{array}$ & .89 & $9.95^{*}$ & & & \\
\hline \multirow[t]{3}{*}{ Subjective norms } & X5: Closest family (belief*recoded motivation). & .73 & & \multirow[t]{3}{*}{.78} & \multirow[t]{3}{*}{.54} & \multirow[t]{3}{*}{.77} \\
\hline & X6: Closest friends (belief*recoded motivation). & .66 & $10.09 *$ & & & \\
\hline & X7: Important others (belief*recoded motivation). & .81 & $10.54 *$ & & & \\
\hline \multirow[t]{5}{*}{ Perceived behavioural control } & $\begin{array}{l}\text { X8: Starting a firm and keeping it viable would be easy for } \\
\text { me. }\end{array}$ & .77 & & \multirow[t]{5}{*}{.88} & \multirow[t]{5}{*}{.60} & \multirow[t]{5}{*}{.88} \\
\hline & $\begin{array}{l}\text { X9: I believe I would be completely unable to start a } \\
\text { business. }\end{array}$ & .90 & $15.86^{*}$ & & & \\
\hline & $\begin{array}{l}\text { X10: I am able to control the creation process of a new } \\
\text { business. }\end{array}$ & .77 & $12.26^{*}$ & & & \\
\hline & $\begin{array}{l}\text { X11: It would be very easy for me to develop a business } \\
\text { idea. }\end{array}$ & .72 & $10.83^{*}$ & & & \\
\hline & $\begin{array}{l}\text { X12: I know all about the practical details needed to start a } \\
\text { business. }\end{array}$ & 69 & $12.10^{*}$ & & & \\
\hline \multirow[t]{3}{*}{ Need for achievement } & X13: Hard work is something I like to avoid (r). & .49 & & \multirow[t]{3}{*}{.72} & \multirow[t]{3}{*}{.46} & \multirow[t]{3}{*}{.67} \\
\hline & $\begin{array}{l}\text { X14: It is important to me to perform better than others on a } \\
\text { task. }\end{array}$ & .79 & $7.155^{*}$ & & & \\
\hline & $\begin{array}{l}\text { X15: I believe I would enjoy having authority over other } \\
\text { people. }\end{array}$ & .73 & $7.148 *$ & & & \\
\hline \multirow[t]{4}{*}{ Risk-taking propensity } & $\begin{array}{l}\text { X16: I am not willing to take risks when choosing a job or a } \\
\text { company to work for. }\end{array}$ & .58 & & \multirow[t]{4}{*}{.80} & \multirow[t]{4}{*}{.51} & \multirow[t]{4}{*}{.80} \\
\hline & $\begin{array}{l}\text { X17: I prefer a low risk/high security job with a steady } \\
\text { salary over a job that offers high risks and high rewards. }\end{array}$ & .82 & $10.05^{*}$ & & & \\
\hline & $\begin{array}{l}\text { X18: I prefer to remain in a job that has problems that I } \\
\text { know about rather than take the risk of working at a new } \\
\text { job that has unknown problems even if the new job offers } \\
\text { greater rewards. }\end{array}$ & .70 & 9.32 & & & \\
\hline & $\begin{array}{l}\text { X19: I view risk on a job as a situation to be avoided at all } \\
\text { costs. }\end{array}$ & .73 & 9.60 & & & \\
\hline \multirow[t]{4}{*}{ Locus of control } & $\mathrm{X} 20$ : My life is determined by my own actions. & .64 & & \multirow[t]{4}{*}{.80} & \multirow[t]{4}{*}{.51} & \multirow[t]{4}{*}{.79} \\
\hline & $\begin{array}{l}\text { X21: When I get what I want, it is usually because I am } \\
\text { lucky (r). }\end{array}$ & .77 & $10.03 *$ & & & \\
\hline & $\begin{array}{l}\text { X22: Whether or not I am successful in life depends mostly } \\
\text { on my ability. }\end{array}$ & .72 & $10.38 *$ & & & \\
\hline & $\begin{array}{l}\text { X23: What happens in my life is mostly determined by } \\
\text { powerful others (r). }\end{array}$ & .65 & $9.60 *$ & & & \\
\hline Perceived contextual support & X24: Entrepreneurs have a positive image in Iranian society. & .56 & & .73 & .36 & .65 \\
\hline & $\begin{array}{l}\text { X25: Qualified consultants and service support for new } \\
\text { companies are available. }\end{array}$ & .59 & 5.93 & & & \\
\hline & $\begin{array}{l}\text { X26: The creative university atmosphere inspires us to } \\
\text { develop ideas for new businesses. }\end{array}$ & .65 & 6.02 & & & \\
\hline Perceived contextual barriers & X27: Banks do not readily give credit to start-up companies. & .58 & & .82 & .48 & .71 \\
\hline & $\begin{array}{l}\text { X28: State laws (rules and regulations) are adverse to } \\
\text { running a company. }\end{array}$ & .63 & 7.95 & & & \\
\hline & $\begin{array}{l}\text { X29: It is hard to find a business idea for a business that } \\
\text { hasn't been realised before. }\end{array}$ & .84 & 8.23 & & & \\
\hline
\end{tabular}

$\mathrm{AVE}=$ average variance extracted; $\mathrm{CR}=$ composite reliability.

$* p<.01$. 
TABLE 3

Correlations and square roots of AVE estimates in bold on the diagonal for all variables

\begin{tabular}{|c|c|c|c|c|c|c|c|c|c|c|c|c|c|c|}
\hline Variable & Mean & SD & 1 & 2 & 3 & 4 & 5 & 6 & 7 & 8 & 9 & 10 & 11 & 12 \\
\hline 1-Entrepreneurial intention & 4.97 & 1.38 & $(.72)$ & & & & & & & & & & & \\
\hline 2-Attitudes towards entrepreneurship & 5.35 & .87 & $.43 * *$ & $(.74)$ & & & & & & & & & & \\
\hline 3-Subjective norms & 3.07 & 5.84 & $.33^{* *}$ & $.18^{* *}$ & $(.73)$ & & & & & & & & & \\
\hline 4-Perceived behavioural control & 4.38 & 1.34 & $.62 * *$ & $.26^{* *}$ & $.27 * *$ & $(.77)$ & & & & & & & & \\
\hline 5- Need for achievement & 5.72 & 1.00 & $.34 * *$ & $.32 * *$ & .06 & $.36^{* *}$ & (.68) & & & & & & & \\
\hline 6-Risk-taking propensity & 3.92 & 1.54 & $.21 * *$ & $.13^{* *}$ & -.09 & $.18^{* *}$ & $.13^{*}$ & $(.71)$ & & & & & & \\
\hline 7-Locus of control & 5.72 & 1.00 & $.23^{* *}$ & $.30^{*}$ & $.12 *$ & $.24 * *$ & $.38 * *$ & .05 & (.71) & & & & & \\
\hline 8-Perceived support & 3.80 & 1.27 & $.14^{*}$ & .02 & .07 & $.13^{*}$ & -.02 & -.01 & .03 & $(.70)$ & & & & \\
\hline 9-Perceived barriers & 4.90 & 1.27 & -.02 & -.03 & .09 & $-.14 *$ & .07 & $-.15^{*}$ & -.02 & $-.20 * *$ & $(.60)$ & & & \\
\hline 10-Gender & - & - & .03 & -.01 & -.09 & .04 & -.03 & .08 & -.10 & -.01 & .04 & & & \\
\hline 11-Age & 22.46 & 2.37 & $.12^{*}$ & .04 & .01 & .10 & .04 & $.20 *$ & .07 & $.13^{*}$ & -.05 & .07 & & \\
\hline 12-Level of education & .23 & .42 & $.20^{*}$ & .07 & -.02 & $.12 *$ & .09 & $.34 *$ & .05 & $.24 *$ & -.03 & .01 & .60 ** & \\
\hline 13-Academic major & - & - & $.17 *$ & .06 & -.02 & .10 & .08 & $.33^{*}$ & .07 & $.19^{*}$ & .01 & -.02 & $.30 * *$ & $.20 *$ \\
\hline
\end{tabular}

Note: The square root of AVE estimate in bold on the diagonal.

$\mathrm{AVE}=$ average variance extracted; $\mathrm{SD}=$ standard deviation.

*Correlation is significant at .05 level (two-tailed).

**Correlation is significant at .01 level (two-tailed).

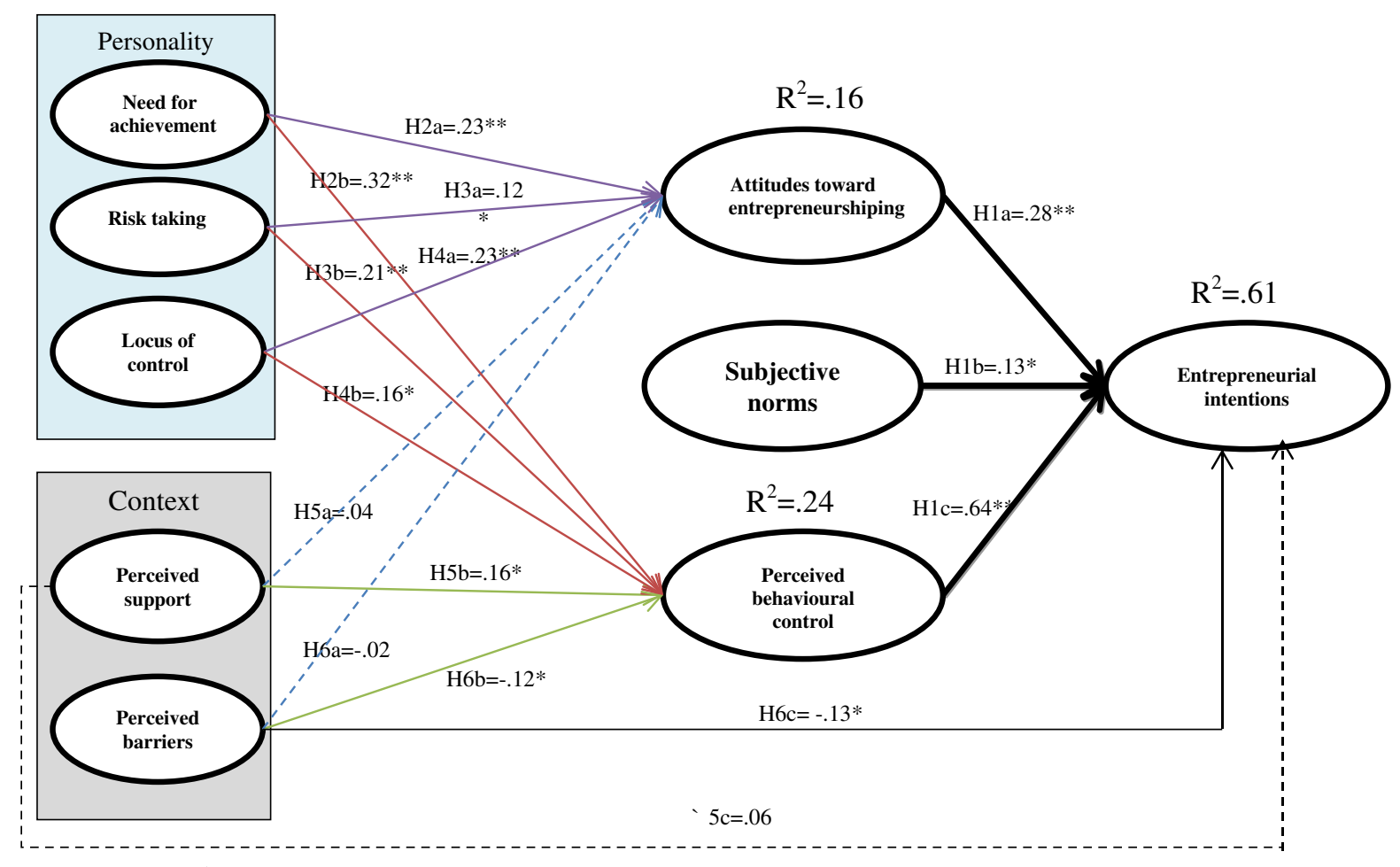

$* \mathrm{P}<.05, * * \mathrm{P}<.01$

The goodness of fit indices: $\mathrm{X}^{2}=836.614 ; \mathrm{x}^{2} / \mathrm{df}=1.67 ; \mathrm{GFI}=0.874 ; \mathrm{TLI}=0.913 ; \mathrm{CFI}=0.922 ; \mathrm{IFI}=0.923$; RMSEA $=0.045$

Figure 2. Path model estimates for the hypothetical model.

showed a total effect of $0.39(0.17+0.22)$. This comparison is nevertheless limited because neither personality nor the environment was covered entirely by the constructs measured in this research. However, for this sample of Iranian students, personality appears to relate more to EI than context.

\section{DISCUSSION}

This study incorporated personality characteristics (need for achievement, risk taking and locus of control) and contextual factors (perceived support and barriers) into the TPB and explored whether and, if so, the extent to 
TABLE 4

Results of structural equation modelling

\begin{tabular}{|c|c|c|c|c|c|}
\hline \multirow[b]{2}{*}{ Hypotheses tested } & & & \multicolumn{3}{|c|}{ Direct effects } \\
\hline & & & Estimate ( $\beta$ value $)$ & SE & CR (t-value \\
\hline H1a: Attitudes towards entrepreneurship & $\rightarrow$ & Entrepreneurial intentions & .28 & .14 & $4.72 * *$ \\
\hline H1b: Subjective norms & $\rightarrow$ & Entrepreneurial intentions & .13 & .01 & $2.35^{*}$ \\
\hline H1c: Perceived behavioural control & $\rightarrow$ & Entrepreneurial intentions & .64 & .08 & $8.09 * *$ \\
\hline H2a: Need for achievement & $\rightarrow$ & Attitudes towards entrepreneurship & .23 & .09 & $2.9 * *$ \\
\hline $\mathrm{H} 2 \mathrm{~b}$ : Need for achievement & $\rightarrow$ & Perceived behavioural control & .32 & .22 & $3.94 * *$ \\
\hline H3a: Risk taking & $\rightarrow$ & Attitudes towards entrepreneurship & .12 & .03 & $1.96^{*}$ \\
\hline H3b: Risk taking & $\rightarrow$ & Perceived behavioural control & .21 & .06 & $3.33 * *$ \\
\hline H4a: Locus of control & $\rightarrow$ & Attitudes towards entrepreneurship & .23 & .04 & $3.17 * *$ \\
\hline H4b: Locus of control & $\rightarrow$ & Perceived behavioural control & .16 & .08 & $2.17 *$ \\
\hline H5a: Perceived contextual support & $\rightarrow$ & Attitudes towards entrepreneurship & .04 & .03 & .590 \\
\hline H5b: Perceived contextual support & $\rightarrow$ & Perceived behavioural control & .16 & .08 & $2.13 *$ \\
\hline H5c: Perceived contextual support & $\rightarrow$ & Entrepreneurial intentions & .06 & .06 & 1.07 \\
\hline H6a: Perceived contextual barriers & $\rightarrow$ & Attitudes towards entrepreneurship & -.02 & .03 & -.240 \\
\hline H6b: Perceived contextual barriers & $\rightarrow$ & Perceived behavioural control & -.12 & .07 & $-1.97 *$ \\
\hline H6c: Perceived contextual barriers & $\rightarrow$ & Entrepreneurial intentions & -.13 & .06 & $-2.35^{*}$ \\
\hline
\end{tabular}

$* p<.05$. ** $p<.01$.

TABLE 5

Effect decomposition for proposed model: direct, indirect and total effects for distal predictors (i.e. personality and perceived contextual factors) of entrepreneurial intentions

\begin{tabular}{lccc}
\hline & \multicolumn{3}{c}{ Effect $(\beta)$} \\
\cline { 2 - 4 } Variables & Direct effect & Indirect effect & Total effect \\
\hline Personality characteristics & & .28 & .28 \\
$\quad$ Need for achievement & - & .17 & .17 \\
Risk taking & - & .16 & .16 \\
Locus of control & - & & \\
Contextual factors & & .11 & .17 \\
Perceived support & .06 & -.09 & -.22 \\
Perceived barriers & -.13 &
\end{tabular}

which these distal factors relate to the motivational factors and EI of higher education students within an Iranian context.

Our results revealed significant relationships between EI and its three motivational antecedents, with a notably high percentage of the variance in EI explained by the model, which is comparable with that found for developed countries. For instance, Linan and Chen's (2009) study of Spanish students showed $58 \%$ of the variance in EI to be explained by a model based upon the TPB. This is contrary to Bruton et al. (2008) who claimed that theories which have been formulated for developed economies, (including the TPB) can be expected to have less explanatory power when applied to developing economies. In keeping with these findings, Iakovleva et al. (2011) have provided empirical evidence for applicability of the TPB in different economic contexts. Additional evidence is thus provided by the present results for the generalisability and applicability of the TPB for the prediction and understanding of EI within a non-Western developing context.

The relative importance of the motivational antecedents of EI, nevertheless, differed within the Iranian context, with SN showing the weakest association and PBC showing the strongest. The EI of Iranian students apparently draws more on individual considerations than on social or normative considerations. And these results thus confirm those of previous studies showing $\mathrm{SN}$ to be least important for EI in a model based upon the TPB (e.g. Karimi et al., 2014; Krueger et al., 2000; Linan \& Chen's, 2009). It is thus possible that the making of entrepreneurial career decisions is of such importance that young people are not likely to be heavily affected by the opinions of others. Another possible explanation concerns the Iranian economic context. The high rate of youth unemployment in Iran (about 30\%) could well limit the effects of perceived approval or disapproval of entrepreneurial activity on the EI of students. As already mentioned, about 38\% of start-ups are driven by necessity in Iran. It is thus possible that the effect of the opinions of others is limited due to the necessity of doing something and thus starting a new business.

In contrast to most studies showing ATE to be the strongest predictor of EI in a developed Western country (e.g. Linan \& Chen, 2009; Nabi \& Linan, 2013) and the findings of a meta-analysis by Schlaegel and Koenig (2014) showing strong SN-EI and ATE-EI associations, we found PBC to be most strongly associated 
with EI in Iran. This discrepancy may stem from the different cultural contexts and developed versus developing statuses of the economies involved. Entrepreneurship is mainly driven by necessity in developing economy like that of Iran; the degree to which the individual has positive or negative perceptions of being an entrepreneur may therefore play less of a role in EI there than in developed economies in particular. A plausible explanation for the particularly strong association of PBC with EI within this study may also stem from Iran-as a country - scoring relatively low on so-called "uncertainty avoidance" (House et al., 2004). When uncertainty avoidance is high, intolerable anxiety may arise in conjunction with trying to do something new and thus uncertain. When uncertainty avoidance is low, as in Iran at the time of this study, individuals may be willing to take more risk than usual, accept the possibility of failure and thus experience relatively less anxiety in conjunction with trying to do something new and uncertain. Iranian students today may thus be relatively unafraid of uncertain situations and, as a result, feel capable of coping with the uncertainty and risks of starting a business (Karimi et al., 2014). Amoros and Bosma (2014) have further found that Iranian respondents report a lower fear of failure as an impediment to starting a business (36\%) than respondents in developed countries such as Italy (49\%), Germany (39\%) and Japan (49\%). The association of PBC with EI can, in light of this information, be expected to be greater in Iran than in a developed economy. Given unstable economic and political country conditions, moreover, confidence in one's ability to start and run a business can be expected to strongly correlate with EI, as we found in our study.

The model derived from the TPB and expanded upon here shows exogenous personality characteristics to indirectly but significantly relate to $\mathrm{EI}$ via the motivational antecedents to EI (both ATE and PBC; Fishbein \& Ajzen, 2010). These findings are in accordance with the findings of previous research showing that personality factors should indeed be incorporated into social-cognitive models of intention and behaviour (e.g. Fini et al., 2012; Lüthje \& Franke, 2003; Nabi \& Linan, 2013). Our findings are also in keeping with those of other studies showing the effects of personality factors on EI to be mediated by the motivational antecedents of EI (e.g. Fini et al., 2012; Lüthje \& Franke, 2003; Obschonka et al., 2010; Zhao et al., 2005). There is thus support for existing theories and the assumption that distal personality characteristics are important for the prediction of entrepreneurial outcomes but only via more proximal motivational and cognitive factors (Fishbein \& Ajzen, 2010; Rauch \& Frese, 2007a).

Our results further show the context-intention link to be clearly mediated by PBC at times. Stated differently, positive perceptions of contextual support can enhance PBC by creating a greater sense of confidence and thereby promote EI. Conversely, perceived contextual barriers can inhibit PBC and thereby EI. This suggests that environmental conditions including facilitative rules and regulations but also loans and credit possibilities must be in place for students to feel more confident about the possibility of starting and managing a new venture.

While these findings generally support this theory and research on the role of perceived contextual factors in the appearance of EI (Fini et al., 2012; Fishbein \& Ajzen, 2010), none of contextual factors significantly related to the motivational factor of ATE. One possible explanation for this finding is that ATE is mostly affected by the close environment of the student (i.e. family and friends). Future research should examine the relative contributions of a greater array of proximal and distal environmental factors on the EI of students and their ATE in particular.

As expected, perceived contextual barriers were found to be not only indirectly but also directly and negatively linked to EI. When individuals perceive conditions as unfavourable to new venture creation, their EI also tends to be directly lower (Lüthje \& Franke, 2003; Nabi \& Linan, 2013). This indicates a limit on the ability of the TPB to fully explain the link between contextual factors and intentions in a variety of situations (Lüthje \& Franke, 2003; Nabi \& Linan, 2013). The strength of the detected context-intention link in our study was nevertheless small.

Perceived contextual support did not directly link to EI in this study, which is in contrast to what others have found (Lüthje \& Franke, 2003). The specific context and characteristics of our sample may explain this discrepancy. Additional research is nevertheless needed to unravel the interrelations between contextual factors and EI in different countries using possibly different operationalisations of the relevant variables to gain sufficient insight into each country setting. Another possible explanation may be that perceived contextual factors relate to a later stage of entrepreneurship (i.e. the decision-making stage occurring between intention and behaviour). Increased support presumably helps bridge the gap between EI and subsequent entrepreneurial behaviour. And when individuals are concretely considering entrepreneurial action, they may be more sensitive to external support than at other times (Fini et al., 2012).

\section{Implications}

With the incorporation of both proximal and distal variables into the modelling of EI, this study contributes to the general literature on EI. Such a configuration of constructs brings together three streams of research: the study of the psychology of entrepreneurship, the study of institutional environments and the study of the TPB. Our results 
call for the integration of personality characteristics and perceived contextual factors into models of EI and show that the roles of distal personality and contextual factors cannot be ignored in models of EI. Finally, by testing specific hypotheses for Iran, we have contributed to calls for research in those countries which are major global players but with sociocultural contexts which are very different from those of western countries (Gupta, Javadian, \& Jalili, 2014).

Personality characteristics emerged as the strongest distal variables to correlate with EI. They can thus be assumed to be more important than contextual factors in the entrepreneurial motivation and intention of students. Policy makers and educators should therefore pay attention to the relevant personality characteristics for the selection and training of students to become entrepreneurs.

According to at least some scholars (e.g. Hansemark, 1998), personality characteristics can be considered learned characteristics and thus open to enhancement and change over time. When funds are limited and need to be carefully dispersed, students with already higher levels of the personality characteristics needed for entrepreneurship should be targeted (Lüthje \& Franke, 2003). In a recent study by Fairlie and Holleran (2012), for example, individuals who were more risk tolerant were found to benefit more from entrepreneurship training than other individuals, which means that this aspect of personality should definitely be taken into consideration during the selection of students for training.

Given that PBC and ATE contributed most to the explanation of the EI of Iranian students, further attention should be paid to supporting these motivational factors in the development of programmes aimed at fostering entrepreneurship. Unfortunately, we still know very little about effective methods for improving PBC within an entrepreneurial context and promoting positive ATE. A challenge for future research is thus to document the effectiveness of various instructional methods and approaches for maximising the antecedents to EI and thereby EI.

\section{Limitations and directions for future research}

This study was cross sectional, which means that firm conclusions cannot be drawn about the direction of causality for the variables included in the model. Longitudinal study is needed to precisely map the contributions of personality characteristics and contextual factors to observed changes in the components of the TPB and EI over time.

The measures used in this study are not the only relevant measures of personality and context. Future research might incorporate broader and possibly more sophisticated measures to map the entrepreneurial context for a more complete understanding of the influence of context on EI and behaviour.

Our data are self-report data and were collected using a single questionnaire, which means that there is a possibility of common method bias. We tried to minimise the possibilities of bias and other common method variance issues, as suggested by Podsakoff, MacKenzie, Lee, and Podsakoff (2003), by creating — for example — proximal separation between the predictor variables and outcome variables, assuring respondent anonymity and providing clear instructions. It is nevertheless possible that all common method bias was not eliminated. Further effort should therefore be expended in the future to remove the possibility of such bias with the use of multiple data sources (for instance).

To close, the participants in our study were students from Iranian universities, which make our findings mostly generalizable to other higher education students and particularly those in developing countries. The expanded, multidimensional framework utilised in our research, however, can certainly be applied in many other contexts for comparison and other purposes.

Manuscript received September 2013 Revised manuscript accepted July 2015 First published online September 2015

\section{REFERENCES}

Ajzen, I. (1991). The theory of planned behaviour. Organizational Behavior and Human Decision Processes, 50(2), $179-211$.

Ajzen, I. (2002). Perceived behavioral control, self-efficacy, locus of control, and the theory of planned behavior. Journal of Applied Social Psychology, 32(4), 665-683.

Amoros, J.E., \& Bosma, N (2014). Global entrepreneurship monitor 2013 global report fifteen years of assessing entrepreneurship across the globe. Babson College, Babson Park, FL: Global Entrepreneurship Research Association. Retrieved from http://www.gemconsortium.org/docs/ download/3106

Bandura, A. (1977). Social learning theory. Englewood Cliffs, NJ: Prentice-Hall.

Baum, J. R., Locke, E. A., \& Smith, K. G. (2001). A multidimensional model of venture growth. Academy of Management Journal, 44, 292-303.

Bruton, G. D., Ahlstrom, D., \& Obloj, K. (2008). Entrepreneurship in emerging economies: Where are we today and where should the research go in the future. Entrepreneurship: Theory and Practice, 32(1), 1-14.

Busenitz, L. W., Gomez, C., \& Spencer, J. W. (2000). Country institutional profiles: Unlocking entrepreneurial phenomena. Academy of Management Journal, 43(5), 994-1003.

Cassidy, T., \& Lynn, R. (1989). A multifactorial approach to achievement motivation: The development of a comprehensive measure. Journal of Occupational Psychology, 62(4), $301-312$. 
Fairlie, R. W., \& Holleran, W. (2012). Entrepreneurship training, risk aversion and other personality traits: Evidence from a random experiment. Journal of Economic Psychology, 33(2), 366-378.

Fini, R., Grimaldi, R., Marzocchi, G. L., \& Sobrero, M. (2012). The determinants of corporate entrepreneurial intention within small and newly established firms. Entrepreneurship: Theory and Practice, 36(2), 387-414.

Fishbein, M., \& Ajzen, I. (2010). Predicting and changing behavior: The reasoned action approach. New York, NY: Psychology Press.

Goethner, M., Obschonka, M., Silbereisen, R. K., \& Cantner, U. (2012). Scientists' transition to academic entrepreneurship: Economic and psychological determinants. Journal of Economic Psychology, 33(3), 628-641.

Gomez-Mejia, L., \& Balkin, D. B. (1989). Effectiveness of individual and aggregate compensation strategies. Industrial Relations, 28, 431-445.

Gupta, V. K., Javadian, G., \& Jalili, N. (2014). Role of entrepreneur gender and management style in influencing perceptions and behaviors of new recruits: Evidence from the Islamic Republic of Iran. Journal of International Entrepreneurship, 12(1), 85-109.

Hair, J. F., Black, W. C., Babin, B. J., \& Anderson, R. E. (2010). Multivariate data analysis: A global perspective. Upper Saddle River, NJ: Pearson Education.

Hansemark, O. C. (1998). The effects of an entrepreneurship program on need for achievement and locus of control of reinforcement. International Journal of Entrepreneurial Behavior \& Research, 14(1), 28-50.

House, R. J., Hanges, P. J., Javidan, M., Dorfman, P., \& Gupta, V. (2004). Culture, leadership and organizations: The GLOBE study of 62 societies. Thousand Oaks, CA: Sage.

Iakovleva, T., Kolvereid, L., \& Stephan, U. (2011). Entrepreneurial intentions in developing and developed countries. Education + Training, 53(5), 353-370.

Karimi, S., Biemans, H. J. A., Lans, T., Chizari, M., \& Mulder, M. (2014). Effects of role models and gender on students' entrepreneurial intentions. European Journal of Training and Development, 38(8), 694-727.

Karimi, S., Chizari, M., Biemans, H. J. A., \& Mulder, M. (2010). Entrepreneurship education in Iranian higher education: the current state and challenges. European Journal of Scientific Research, 48(1), 35-50.

Kautonen, T., van Gelderen, M., \& Fink, M. (2015). Robustness of the theory of planned behavior in predicting entrepreneurial intentions and actions. Entrepreneurship: Theory and Practice, 39(3), 655-674.

Kolvereid, L., \& Isaksen, E. (2006). New business start-up and subsequent entry into self-employment. Journal of Business Venturing, 21(6), 866-885.

Krueger, N. F., Reilly, M. D., \& Carsrud, A. L. (2000). Competing models of entrepreneurial intentions. Journal of Business Venturing, 15(5-6), 411-432.

Linan, F., \& Chen, Y. (2009). Development and cross-cultural application of a specific instrument to measure entrepreneurial intentions. Entrepreneurship: Theory and Practice, 33(3), 593-617.

Lumpkin, G.T., \& Erdogan, B. (1999). If not entrepreneurship, can psychological characteristics predict entrepreneurial orientation? - A pilot study. Working paper, University of Illinois Chicago, Chicago, IL.

Lüthje, C., \& Franke, N. (2003). The 'making' of an entrepreneur: Testing a model of entrepreneurial intent among engineering students at MIT. $R \& D$ Management, 33(2), 135-147.

McClelland, D. C. (1961). The achieving society. Princeton, NY: Van Nostrand.

Mueller, S. L., \& Thomas, A. S. (2001). Culture and entrepreneurial potential: A nine country study of locus of control and innovativeness. Journal of Business Venturing, 16(1), 51-75.

Nabi, G., \& Linan, F. (2013). Considering business start-up in recession time: The role of risk perception and economic context in shaping the entrepreneurial intent. International Journal of Entrepreneurial Behavior \& Research, 19(6), 633-655.

North, D. C. (2005). Understanding the process of economic change. Princeton, NJ: Princeton University Press.

Nunnally, J. C., \& Bernstein, I. H. (1994). Psychometric theory (3rd ed.). New York, NY: McGraw-Hill.

Obschonka, M., Silbereisen, R. K., \& Schmitt-Rodermund, E. (2010). Entrepreneurial intention as developmental outcome. Journal of Vocational Behavior, 77(1), 63-72.

Phillips, J., \& Gully, S. (1997). Role of goal orientation, ability, need for achievement, and locus of control in the self-efficacy and goal-setting process. Journal of Applied Psychology, 82(5), 792-802.

Podsakoff, P. M., MacKenzie, S. B., Lee, J.-Y., \& Podsakoff, N. P. (2003). Common method biases in behavioral research: A critical review of the literature and recommended remedies. Journal of Applied Psychology, 88, 879-903.

Rauch, A., \& Frese, M. (2007a). Born to be an entrepreneur? Revisiting the personality approach to entrepreneurship. In J. R. Baum, M. Frese, \& R. A. Baron (Eds.), The psychology of entrepreneurship (pp. 41-65). Mahwah, NJ: Lawence Earlbaum.

Rauch, A., \& Frese, M. (2007b). Let's put the person back into entrepreneurship research: a meta-analysis of the relationship between business owners' personality characteristics and business creation and success. European Journal of Work and Organizational Psychology, 16(4), 353-385.

Robinson, P. B., Stimpson, D. V., Huefner, J. C., \& Hunt, H. K. (1991). An attitude approach to the prediction of entrepreneurship. Entrepreneurship Theory and Practice, 15(4), 13-31.

Rotter, J. B. (1966). Generalized expectancies for internal versus external control of reinforcement. Psychological Monographs, 80(1), 609.

Schlaegel, C., \& Koenig, M. (2014). Determinants of entrepreneurial intent: A meta-analytic test and integration of competing models. Entrepreneurship: Theory and Practice, 38(2), 291-332.

Shapero, A. (1982). Social dimensions of entrepreneurship. In C. Kent, et al. (Eds.), The encyclopedia of entrepreneurship (pp. 72-90). Prentice Hall: Englewood Cliffs, NJ.

Shaver, K. G., \& Scott, L. R. (1991). Person, process, choice: The psychology of new venture creation. Entrepreneurship: Theory and Practice, 16(4), 23-44. 
Soomro, B. A., \& Shah, N. (2015). Developing attitudes and intentions among potential entrepreneurs. Journal of Enterprise Information Management, 28(2), 304-322.

Stewart, W. H., Jr., \& Roth, P. L. (2001). Risk propensity differences between entrepreneurs and managers: A meta-analytic review. Journal of Applied Psychology, 86(1), 145-153.

Taormina, R. J., \& Lao, S. K.-M. (2007). Measuring Chinese entrepreneurial motivation: Personality and environmental influences. International Journal of Entrepreneurial Behavior \& Research, 13(4), 200-221.

Welter, F., \& Smallbone, D. (2011). Institutional perspectives on entrepreneurial behavior in challenging environments. Journal of Small Business Management, 49(1), 107-125.
World Bank (2011). How we classify countries. Retrieved from http://data.worldbank.org/about/country-classifications

World Bank (2014). Doing Business 2015: Going Beyond Efficiency. Washington DC: The World Bank.. Available at: http://www.doingbusiness.org/reports/global-reports/doingbusiness-2015

Zhao, H., \& Seibert, S. E. (2006). The Big Five personality dimensions and entrepreneurial status: A meta-analytical review. Journal of Applied Psychology, 91(2), 259-271.

Zhao, H., Seibert, S., \& Hills, E. (2005). The mediating role of self-efficacy in the development of entrepreneurial intentions. Journal of Applied Psychology, 90(6), 1265-1272.

APPENDIX A. OVERVIEW OF QUESTIONNAIRE ITEMS AND THEIR SOURCES

\begin{tabular}{|c|c|c|}
\hline Construct & Research reference & No. of item \\
\hline Entrepreneurial intentions & Linan and Chen (2009) e.g. "I'm ready to do anything to be an entrepreneur." & 6 \\
\hline Attitudes towards entrepreneurship & $\begin{array}{l}\text { Linan and Chen (2009) e.g. "Being an entrepreneur implies more advantages than disadvantages } \\
\text { for me." }\end{array}$ & 5 \\
\hline Subjective norms & $\begin{array}{l}\text { This scale included two separate questions: belief (e.g. "I believe that my closest family thinks } \\
\text { that I should start my own business") and motivation to comply (e.g. "I care about my closest } \\
\text { family's opinion with regard to me starting my own business"). The belief items were recoded } \\
\text { into a bipolar scale (from }-3 \text { to }+3 \text { ) and multiplied with the respective motivation-to-comply } \\
\text { items (Kolvereid \& Isakson, 2006; Krueger et al., 2000). }\end{array}$ & 6 \\
\hline Perceived behavioural control & Linan and Chen (2009) e.g. "Starting a firm and keeping it viable would be easy for me." & 6 \\
\hline Need for achievement & Cassidy and Lynn (1989) e.g. "It is important to me to perform better than others on a task." & 7 \\
\hline Risk taking propensity & $\begin{array}{l}\text { Gomez-Mejia and Balkin (1989) e.g. "I'm not willing to take risks when choosing a job or a } \\
\text { company to work for." }\end{array}$ & 4 \\
\hline Locus of control & Rotter (1966) e.g. "My life is determined by my own actions." & 5 \\
\hline Perceived contextual support & $\begin{array}{l}\text { Lüthje and Franke (2003) e.g. "The creative atmosphere at my university inspires the } \\
\text { development of ideas for new businesses." }\end{array}$ & 3 \\
\hline Perceived contextual barriers & Lüthje and Franke (2003) e.g. "Banks do not readily give credit to start companies." & 3 \\
\hline
\end{tabular}

